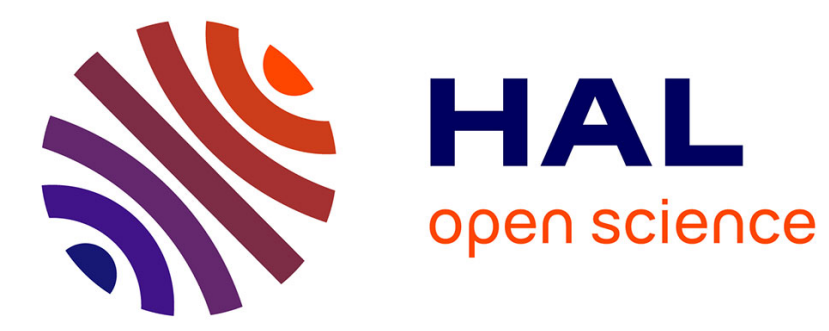

\title{
How Green is my Firm? Workers' Attitudes and Behaviors towards Job in Environmentally Related Firms
}

Joseph Lanfranchi, Sanja Pekovic

\section{- To cite this version:}

Joseph Lanfranchi, Sanja Pekovic. How Green is my Firm? Workers' Attitudes and Behaviors towards Job in Environmentally Related Firms. Ecological Economics, 2014, 100, pp.16-29. 10.1016/j.ecolecon.2013.12.019 . halshs-01081059

\section{HAL Id: halshs-01081059 \\ https://shs.hal.science/halshs-01081059}

Submitted on 6 Nov 2014

HAL is a multi-disciplinary open access archive for the deposit and dissemination of scientific research documents, whether they are published or not. The documents may come from teaching and research institutions in France or abroad, or from public or private research centers.
L'archive ouverte pluridisciplinaire HAL, est destinée au dépôt et à la diffusion de documents scientifiques de niveau recherche, publiés ou non, émanant des établissements d'enseignement et de recherche français ou étrangers, des laboratoires publics ou privés. 


\title{
How Green is my Firm? Workers' Attitudes and Behaviors towards Job in Environmentally- Related Firms 1
}

\author{
Joseph Lanfranchi (Corresponding author) \\ LEMMA, Université Panthéon-Assas and Centre d'Etudes de l'Emploi \\ 92 rue d'Assas, 75005 Paris, France \\ tel : (33) 155425030. \\ joseph.lanfranchi@cee-recherche.fr
}

Sanja Pekovic

University Paris-Dauphine DRM-DMSP (CNRS UMR 7088) and Centre d'étude de l'emploi sanja.pekovic@dauphine.fr

\begin{abstract}
The implementation of environmental standards can be facilitated by motivating workers with pro-social preferences. Therefore, we study if employees working for firms achieving registration for environmental-related standards are more likely to display positive attitudes toward their job, to be actively involved in their jobs and to donate effort. Using a French matched employer-employee database, we find that these "green employees" report a significantly higher perception of usefulness and equitable recognition at work. Besides, they are more likely to work uncompensated overtime hours. Finally, if the adoption of environmental standards is shown to have no direct influence on job involvement, we expose how it indirectly impacts job involvement through the mediation of employees' reported perception of usefulness and equitable recognition at work.
\end{abstract}

Key words: environmental-related standards; pro-social motivation; workers' attitudes and behavior.

JEL codes: Q50; J28;

\footnotetext{
1 We thank Juliette Arnal, Sandra Cavaco, Patricia Crifo, Christophe Daniel, Magali Delmas, Marc-Arthur Diaye, Nathalie Greenan, Sylvie Hamon-Cholet and the participants at the seminars in the Centre d'Etudes de l'Emploi, the University of California, Los Angeles, the 2009 International Conference for Quality Management and Environment, the 2010 Journées de Microéconomie Appliquée and the 2011 The Economics of Corporate Social Responsibility Conference. The authors started this paper when Sanja Pekovic was a PhD student at Centre d'études de l'emploi and University Paris-Est. Sanja Pekovic gratefully acknowledges the financial support for this work from the AFNOR "Performance des Organisations" endowment in collaboration with the Paris-Dauphine Foundation.
} 


\section{Introduction}

In post-industrial societies, firms need both a legal right and a "social license" to operate. Therefore, in addition to the well-known profit maximization goal, entrepreneurs may invest in social responsibility, i.e. a firm may commit to implementing procedures and policies devoted to improving the well-being of employees, customers and any institution representative of the local community (Turban and Greening, 1997). Firms can meet the requirements of "social licensors" by adopting environmentalrelated standards because these standards will lead the firms to conduct business in a more socially responsible manner. ${ }^{2}$

A growing body of literature has been concerned with the motivation for adopting environmentallyrelated standards (e.g., Grolleau et al., 2007a, b; Ambec and Lanoie, 2008) and their impacts on firm performance (e.g., Darnall and Sides, 2008; Darnall et al., 2008). Among the different rationales for environmental activities, the pressure of stakeholders on firms to make valuable investments ensuring good environmental performance has been empirically evaluated. For instance, Nishitani (2009) highlighted the role of standardization as a signal of commitment to environmental protection for stakeholders who are unable to control the firm, like foreign customers. Also, Lannelongue and González-Benito (2012) found that the likelihood of implementation of an environmental management system rises with the pressure from different groups of stakeholders, like shareholders, employees, commercial buyers, regulators, environmental and community organizations but not the household consumers. Nevertheless, once the firms become environmentally registered, their environmental concerns are related only to the pressure from internal stakeholders, like shareholders and employees, neglecting pressures from external stakeholders. However, to date, scholars have neglected to study whether or how those standards impact internal stakeholders' attitudes and behaviors. Therefore, this paper aims to examine how the utilization of environmental-related standards ${ }^{3}$ impacts employees' attitudes toward their employment relationship in terms of usefulness and equitable recognition, and

\footnotetext{
${ }^{2}$ Following Brekke and Nyborg (2007), we will term environmentally registered firms as "green" firms, even if we are conscious that this certification may have an additional objective than improving environmental performance (see Lannelongue and Gonzalez-Benito, 2012).

3 We use the term "environmental-related standards" to define the following standards: ISO 14001 standard, organic labeling or fair trade.
} 
behaviors such as job involvement and effort at work. ${ }^{4}$ Finding a positive link between environmentally-related standards and employees attitudes and behavior will improve understanding of why employees' environmental pressure is still considered as important even after firms' registration for environmental standards (Lannelongue and González-Benito, 2012).

A first rationale for suggesting a positive impact of environmental-related standards on employees' attitudes, job involvement and effort can be traced to Brekke and Nyborg's model (2007), which shows that workers who exhibit preferences that depend positively on the level of social welfare are ready to provide a form of labor donation to environmentally responsible employers. This labor donation could take the form of a lower reservation wage or a higher level of effort. Hence, one of the driving forces inducing firms to invest in environmental-related activities can be found in the desire to recruit pro-socially motivated applicants. Doing so ensures that a firm's employees are highly motivated and involved in their jobs. Therefore, green entrepreneurs may expect an advantage in labor productivity to compensate for the costs of environmental-related investments.

A second explanation derives from the moral prejudice that employees may face if their employer undertakes business policies that will damage their social reputations. According to social identity theory, individuals evaluate their self-image by comparing the main features of the social group to which they belong with the characteristics of other groups (see Ellemers et al., 2002, and Haslam, 2001, for extensive discussion of social identity theory). Therefore, the employees of a firm that commits itself toward a better environmental performance should experience higher motivation, as they benefit from their employer's good reputation and image in the community. ${ }^{5}$ As stressed by Akerlof and Kranton (2005), if a firm can inculcate a sense of common identity in its workforce, the firm may use such non-pecuniary incentives to induce its workers to invest high degrees of effort.

Finally, work reorganization induced by the adoption of environmentally-related standards may improve employees' attitudes, job involvement and effort through two channels. First, work reorganization provides new working opportunities for employees, such as the opportunity to

\footnotetext{
${ }^{4}$ We follow the definition of attitude given by Eagly and Chaiken (1998) "a psychological tendency that is expressed by evaluating a particular entity with some degree of favor or disfavor". Therefore, job involvement and the intensity of effort are employees' behaviors while employees' assessment of the usefulness of their job and if they are fairly treated are attitudinal evaluations.

${ }^{5}$ For a survey of the evidence on individuals' concerns with employer image, see Bénabou and Tirole (2010).
} 
participate in the decision-making process, more autonomy and the opportunity to enhance one's skills and leadership, which may all lead to job enrichment and (most likely) job involvement. Second, an employer's commitment to environmental policies can be associated with greater attention to safety practices and a decrease in the number of environmental incidents. Employee's physical security belongs to a large set of valuable but non-pecuniary characteristics that can be expected to enhance the employee's reported perception of being equitably recognized by his or her employer.

For these three reasons, employers may expect that the implementation of environmental-related standards leads to an increase of employees' well-being at work and effort. This conjecture has never been empirically tested while a large body of research has studied the effects of "High Performance" and "High Involvement" practices on various employees' outcomes with mixed results (see Godard, 2010 for an overview). One strand of this literature has tried to identify whether the use of organizational and human resources innovations impacted on subjective evaluation of well-being, like job satisfaction (see e.g., Bryson et al., 2013 and Bockerman et al., 2012 for recent evidence). Another strand has focused on their influence on employees' behaviour at work, like the extent of physical and discretionary effort (Green, 2004) and voluntary turnover (see e.g., Cottini et al., 2011). In this work, we follow both roads and explore the effect of environmental-related standards on specific facets of well-being at work and indicators of effort.

In the classic tradition of Locke (1976), job satisfaction is an emotional state resulting from the appraisal by employee of how the different facets of his job help to achieve his values. Here, we do not have access to such overall measure of well-being at work and then choose to focus on two facets of the job that are first likely to be impacted by environmental-related standards and second have been shown to be major determinants of well-being at work. The first facet is the employee's perception of equitable treatment resulting from his balance between the demands that his job imposes and the outcomes he receives from it. The use of environmental management standards is expected to alter the level of job demands and outcomes in two opposite directions. Employees' effort may become more intense to cope with the new standardized procedures together with the need of improved skill and training. At the same time, the job outcomes may increase with the diminution of environmental hazardous practices and the contentment to participate to a more socially responsible productive 
activity. In the literature this perception of equity at the workplace has been shown to be linked with higher job satisfaction (see Warr, 2007). The second facet is the perception that the employee's job is useful to others. Implementing an environmentally-related standard is likely to help the employees achieving their pro-socialvalues in the job. Indeed, the usefulness of one's job to society has also been shown to fuel one's job satisfaction (e.g. Souza-Poza and Souza-Poza, 2000, Clark, 2010).

In supplement to these two attitudes, we also study how two indicators of effort, employees' selfreported job involvement and amount of uncompensated overtime hours, are impacted by the implementation of environmental-related standards. In both cases, we expect that corporate social investments made by firms will drive the employees to donate labour for pro-social investment (see Gregg et al., 2011, for a study of labour donation).

Therefore, the gains achieved by the employers from the environmental-related standardization would come partly from the reduction of their labor costs. In fact, reported perception of equity and usefulness in one's job have been found to be associated with the likely determinants of worker productivity, such as lower levels of absenteeism (e.g., DeBoer et al., 2002) and job withdrawal (Donovan et al., 1997), lower risk of poor health (van Vegchel et al., 2005), higher morale (Bewley, 2007) and protection from psychological stress (Takaki et al., 2010). Similarly, job involvement has also been identified as a factor that increases employee effort and performance (Diefendorff et al., 2002).

As noted by Ambec and Lanoie (2008), it would be useful to explore empirically the effects of implementing environmental-related standards on labor costs. Although we cannot directly test this relationship, the first original contribution of this paper is an assessment of the likelihood that a firm will improve its labor efficiency. Hence, we investigate the effect of working for a firm registered to an environmental-related standard on the likely predictors of labor productivity. The second point of interest of our study comes from a matched employer-employee dataset, the Organizational Change and ICT Survey (COI 2006), which provides a representative sample of French private firms with more than 20 employees. Both employers and employees are interviewed. The former is interrogated with regard to firm practices, technological changes and organizational changes and the latter with regard to the work organization, the content of the employees' jobs, and their attitudes and opinions. 
Importantly, this large employer-employee database (7,700 firms and 14,369 randomly selected employees) provides information about the employers' adoption of environmental-related standards along with the employees' evaluations of their working conditions and job characteristics. Additionally, we control for a detailed set of worker, job and firm characteristics to properly isolate the effect of environmental-related standards on employees' attitudes, job involvement and effort. The utilization of French data has the further advantage of allowing us to analyze the consequences of implementing environmental-related standards in organizations outside the more extensively studied US case (Delmas and Pekovic, 2012). From that point of view, France appears to be an interesting case for assessing the strength of environmental motivations because French voters showed their growing sense of concern about environmental questions in the 2009 European polls, where French voters elected the highest number of Green Party representatives in the European Parliament.

The paper is structured as follows. Section 2 reviews the literature on the link between firms' proenvironmental behaviors and workers' attitudes. Section 3 presents the data and model specification. The results are provided and discussed in section 4 . Section 5 concludes and suggests future directions and policy implications.

\section{Environmental-related standards and employees' attitudes and behavior at work}

In this section, we review how the previous theoretical and empirical literature explains the link between the implementation of environmental-related standards and workforce attitudes and behavior. In fact, the implementation of environmental-related standards represents a significant organizational change within a firm. It can be defined as a self-motivated effort at internalizing environmental externalities by adopting management practices that enable the firm to make continuous improvements in its production methods and environmental performance (Khanna and Anton, 2002). However, such a change may imply considerable investments and raises a rational question: is it profitable to invest in such environmental-related standards?

The Porter hypothesis offers a positive answer to this question. The hypothesis states that the different types of returns obtained from environmental innovations may compensate for their implementation 
costs. A recent survey by Ambec and Lanoie (2008) listed seven channels through which environmental-related standards may provide benefits to firms or reduce their costs: better access to markets, greater possibilities for product differentiation, commercialization of pollution-control technology and savings on regulatory costs, material energy and services, and capital and labor costs. Of particular interest for our research is the effect of working in an environmentally registered firm on the likely predictors of labor productivity and costs, such as employees' reported perception of usefulness and equitable recognition and the levels of job involvement and work effort.

The positive impact of environmental-related standards on employee attitudes and behavior may be rationalized by at least two types of arguments. The first postulates that the implementation of environmental-related standards will help firm to improve their relationship with workers, and to attract and motivate workers with pro-social preferences. The second identifies the indirect effects on employee attitudes and behaviours caused by changes in work organization and the improvements in working conditions due to the registration to environmental-related standards. The following discussion will develop these two perspectives.

To help their workforce understand and commit to environmental issues, firm managers need to find strong motivational factors. Generally, the intrinsic motives that are likely to encourage employees have an ideological character. Hence, pro-social motivation, which we define as an individual's aspiration to have a positive impact on the well-being of other people and groups within society, may help to improve work commitment. For this reason, voluntary environmental-related initiatives may improve human resource management if the firm successfully attracts and motivates workers who share these values. ${ }^{6}$ Our main theoretical reference for rationalizing this intuitive argument is Brekke and Nyborg's (2007) model, which shows that if workers have preferences that depend positively on the well-being of others, they are likely to self-select themselves to work in "green firms" and to work harder for environmentally responsible employers. Consequently, the benefits obtained from efficiently recruiting pro-socially motivated workers may outweigh the costs of environmental-related investments. From the workers' point of view, participating in an environmentally responsible firm's

\footnotetext{
${ }^{6}$ Notably, Grolleau et al. (2007b) showed that ISO 14001 registration among French agro-food firms was mainly driven by the desire to improve human resource management.
} 
activities may enhance their reported perception that their jobs are useful to the rest of the society and increase the rewards that they obtain from the job.

Similar to Brekke and Nyborg's model (2007), labor donation theory ${ }^{7}$ postulates that the goals, alleged values and management practices of productive organizations help attract and motivate individuals who prefer to work for employers devoted to socially desirable objectives. Labor donation can take the form of a specific level of involvement in the firm's activity. If employers cannot perfectly control the effort level of their workforce, pro-social motivation ensures that their workers are more likely to work hard. This process is reminiscent of the fair wage-effort version of efficiency wage theory, where a worker's effort is exchanged for a fair compensation. However, in this case, the non-pecuniary benefits obtained from participating in environmental-related activities stimulate workers' job involvement. Besides, the large investment costs associated with the implementation of such standards act as a commitment on the part of the firm not to divert the employee donation of effort towards increasing its profits at the expense of social objectives. Therefore, environmental-related standards registration acts as a signal of costly, and hence credible, commitment and helps to screen and motivate pro-socially motivated workers.

Prior empirical evidence has shown that non-profit and public sector workers with pro-social motivations are more likely to accept lower wages (Narcy, 2011), donate their labor (as measured by unpaid overtime) (Gregg et al., 2011), be less absent (Lanfranchi and Narcy, 2010) and declare themselves significantly more satisfied at work (Benz, 2005; Lanfranchi and Narcy, 2008). Accordingly, this type of motivation, which is based on individual values, may generate benefits both for employees in terms of reported perception of usefulness and for employers in terms of increased productivity.

Moreover, individuals also become involved in a given social group's activities whenever these activities are evaluated positively by society. According to social identity theory, individuals assess their social identity based on their adherence to various organizations, including the firm for which they work. However, these organizations develop their reputations in society through competition,

\footnotetext{
${ }^{7}$ Originally, the theory was put forward to explain how non-profit organizations that offer goods and services aimed at generating social benefits may successfully recruit workers who are ready to accept lower wages than those they could obtain in the private sector (Preston, 1989).
} 
comparison and judgments. In this case, an individual's identification with the organization is the process through which such evaluations are transformed into an evaluation of the individual's own personality. Therefore, employee attitudes and behavior in the workplace should be favorably influenced by a positive social perception of the employer's social performance. Hence, a firm's improved environmental performance may positively influence its employees' motivation and job involvement. Bénabou and Tirole (2010) review the evidence on how self-image concerns influence pro-social behavior in domains such as volunteerism, blood donation or participation in elections.

In the labor market context, there is some sparse evidence that seems to confirm employees' concerns regarding the social benefits generated by participating in their employers' activities. Hence, the International Social Survey Program (in 1989, 1997 and 2005) records that the largest increase in employees' work values is registered for the two following items: "In my work I can help other people" and "my work is useful to society" (Clark, 2009). In addition, in a study of Cornell University graduates, Frank (1996) indicates that personal values affect the choice of employers and the level of reservation wages. The author's survey results show that 88 percent of the sampled graduates would prefer to work for the American Cancer Society rather than Camel Cigarettes, with an average compensating wage premium of approximately $\$ 24,000$ per year. This finding confirms that individuals are likely to accept lower wages and thus allow the firm to balance the cost of its socially responsible operations. Additionally, Turban and Greening (1997) show a positive correlation between the ratings of a firm's Corporate Social Responsibility and its degree of attractiveness for workers. More in line with the precise topic of our study, the empirical results found by Grolleau et al.'s (2012) show that if French firms have registered for environmental-related standards, they experience fewer difficulties in recruiting both professional and non-professional employees.

The second perspective is related to the fact that the adoption of environmental-related standards may trigger other changes in the work organization and indirectly influence employee attitudes. In fact, similar to the use of high-performance work practices, the adoption of environmental-related standards may induce employer reorganizations that provide workers with opportunities to participate in the decision-making process, be more autonomous, enhance their skills, or improve their leadership. These new opportunities could be further associated with improvements in the balance between effort 
and rewards. Moreover, several scholars argue that adoption of high-performance work practices makes employees become highly motivated and committed since their social-psychological needs are fulfilled (e.g., Cappelli and Rogovsky, 1998). For instance, Appelbaum et al. (2000) argue that the opportunity to participate in decision making helps to create trust between workers and supervisors and to produce intrinsic rewards. In turn, trust and intrinsic rewards are positively associated with higher commitment, job satisfaction and lower stress. Nevertheless, employer reorganization may have conflicting effects on employee well-being because the reorganization process may often be associated with higher demands within the job and therefore, with intensification of labor effort (e.g., Green, 2004). It is difficult from the whole literature to conclude. If high performance workplace practices tend to have a number of implications for employees, the positive or negative nature of these applications appears to vary depending on the level of high performance workplace practices involvement, the form of work organization, the degree of unionization of the firm and ultimately the specific high performance workplace practices adopted (see Godard, 2010, Bryson et al., 2013).

In addition to these job design effects, environmental-related standards may have other indirect effects on overall reported perception of equitable recognition and job involvement by impacting working conditions. Previous scholars have argued that work accidents, injuries, and bad working conditions result in decreased employee morale, organizational commitment and job satisfaction (Michael et al., 2005). Therefore, as the adoption of environmental-related standards improves the health and safety conditions of employees by mitigating pollution, reducing contact with hazardous materials and diminishing bad odors and noise, one may expect these standards to generate positive effects on the workers' reported perception of being equitably recognized.

\section{Data and model specification}

The survey 
The data are extracted from the French Organizational Change and ICT's (COI) 2006 survey. ${ }^{8}$ This survey was created by the researchers and statisticians from the National Institute for Statistics and Economic Studies (INSEE), the Ministry of Labor (DARES) and the Center for Labor Studies (CEE). This collaboration generated a large amount of knowledge and expertise, which has made it possible to put together questionnaires for the private firms and their workforces.

Between November 2005 and April 2006, 17, 000 firms were sampled to answer a questionnaire sent by postal mail from the population of all French firms with 10 or more employees and belonging to all private industries except agriculture, forestry, fishing, mining and services to individuals. The response rate was a high $85 \%$ with a total of 14,384 usable questionnaires. Each firm completed a self-administered questionnaire concerning its utilization of information technologies and work organization practices in 2006 and the changes that have occurred since 2003 . The firms were also interrogated with regard to the economic goals of their organizational changes and the economic context in which those decisions were made.

Of the firms that responded, 7,700 private firms with 20 or more employees served as the basis for the survey of employees. Within each surveyed firm, randomly selected employees provided details about their personal socio-economic characteristics, the nature of their labor contracts, the characteristics and contents of their jobs, the work organization and their attitudes about their jobs. The original dataset included 14,369 employees, but we were unable to match 346 observations with their original employers. Furthermore, to obtain information about worker compensation, we merged the COI survey with another French administrative database, Employer's annual declaration of payroll data (DADS), which contained information on employee compensation. However, direct information on net wages was unavailable, and each individual worker was linked with the percentile of the countrywide wage distribution to which he or she belongs. Furthermore, we used the Annual Enterprise Survey (EAE) to obtain information about the firm export levels. However, as the population of the EAE does not include firms operating financial and research and development activities, our final matched sample is not perfectly representative of the population of French firms with at least 20 employees from all private industries except for agriculture, forestry, fishing, extracting and quarrying

\footnotetext{
${ }^{8}$ More details about the design and scope of this survey are available at http://www.enquetecoi.net./
} 
and services to households. Finally, after deleting additional firms and employees that did not provide all of the relevant information for our study, we are left with 11,603 usable observations.

\section{The indicators of employee attitudes and effort}

The employees' reported perceptions about their employment relationships are defined as the employees' attitudes toward or evaluations of a specific object (i.e., the job). The previous literature has measured these concepts with single indicators and/or a multiple items scale (see Warr, 2007). Because our survey was not specifically designed to study these dimensions in detail, we do not have the set of questions necessary to construct a multiple items scale at our disposal. Therefore, we will focus on distinct binary indicators of worker attitudes ${ }^{9}$.

The first indicator of employee attitude that we will study is called USEFUL and is intended to measure employees' reported perception regarding the usefulness of their jobs. This indicator takes a value of 1 if the employee thinks that his or her work is useful to others and is particularly interesting in the context of pro-social motivation. We expect this indicator to help capture the degree to which one feels that his or her work aids society. Our second attitudinal variable of interest is related to the reported perception of equitable recognition in the employer-employee relationship: employees judge that they are equitably recognized by their employers by comparing their inputs and rewards to an internal standard. Therefore, our second binary dependent variable, denoted RECOGNITION, captures this comparison and takes a value of 1 if the employee believes his or her work is equitably recognized when the employee weigh what he or she brings to the firm against the benefits he or she receives.

Job involvement, originally defined by Lodahl and Kejner (1965) as the "degree to which a person is psychologically identified with his work," has frequently been measured on a scale constructed from a list of items. Because we cannot construct a classic job involvement scale, we choose to capture two psychological and behavioral dimensions of job involvement and employee effort. These two dimensions are measured using two binary variables, INVOLVEMENT and NON COMPENSATED

\footnotetext{
9 Attitudes are difficult to measure as they are an individual construct that cannot be observed directly. Therefore, we have to rely on binary indicators reported by the employee.
} 
OVERTIMES, which are equal to 1 if the employee states that he or she is heavily involved in his or her job and if the employee is not compensated for his or her supplementary work hours, respectively. Agreeing to work compensation-free for supplementary hours can be viewed as a type of effort donation.

\section{The measure of environmental-related standards}

To understand whether environmental-related standards impact employee attitudes, job involvement and work effort, we use the variable denoted STANDARDS, which is a binary variable equal to 1 if the firm was registered in 2006 in accordance with one of the following standards: ISO 14001 standard, organic labeling or fair trade. ${ }^{10} 11$

\section{The empirical model}

Because the same unobservable factors may impact both the employees' likelihood of working for an environmentally registered firm and the employees' attitudes, job involvement and effort, we apply a bivariate probit model to correct for endogeneity (Greene, 2003). The model relies on a simultaneous estimation approach in which the factors that determine the choice of working at a firm registered for an environmental-related standard are estimated simultaneously with the factors that explain the employees' attitudes and behaviors. The variables used in the estimation, their definitions and both the unweighted and weighted sample statistics are presented in Table 1. ${ }^{12}$

[Insert Table 1 around here]

\footnotetext{
10 Unfortunately, we cannot distinguish among these three standards because they were put together under the same survey question. However, because the implementation of these different types of standards entails similar pro-social objectives, we expect that their impacts on employee attitudes, job involvement and effort will be similar. Additionally, French firms primarily adopt ISO 14001, EMAS and 1.2.3. Environment.

11 In our database, there is no direct question to the employees allowing insuring that they are aware of the fact that the firm is environmentally registered. However, AFNOR, the French Association for standardization (Baron, 2005), published a guide to help managers with the environmental management where they raise this issue: "Top management shall define the organization's environmental policy and ensure that, within the defined scope of its environmental management system, it is communicated to all persons working for or on behalf of the organization". Therefore, we assume that employees are likely to be informed about firm's registration.

12 The weighted descriptive statistics correspond to a picture of the sampled population of firms in 2006 . However, sampling weights were not used in our econometric regressions.
} 
We denote $Y_{1}$ as our observed binary variable corresponding to whether the worker is employed in a firm registered for an environmentally-related standard, whereas $Y_{2 k}, k=(1, \ldots 4)$, correspond to the employees' observed perception of usefulness and recognition (USEFUL and RECOGNITION) and job involvement and effort (INVOLVEMENT and NON COMPENSATED OVERTIMES), respectively. These variables are defined as follows:

$$
\begin{aligned}
& Y_{1}=1 \quad \text { if } Y_{1}^{*}>0, \\
& Y_{1}=0 \text { otherwise. } \\
& Y_{2 k}=1 \text { if } Y_{2 k}^{*}>0, \\
& Y_{2 k}=0 \text { otherwise. }
\end{aligned}
$$

$Y_{1}^{*}$ and $Y_{2 k}^{*}$ are latent variables measuring respectively the unobserved gains for an employee working for a firm that is registered for an environmentally-related standard and the unobserved levels of the employee's reported perception regarding the usefulness of his or her job, equitable recognition, job involvement and effort, respectively. We consider the following bivariate probit model:

$$
\left\{\begin{array}{l}
Y_{1}^{*}=\alpha_{1}+\beta_{1} X_{1}+\delta Z_{1}+\mu_{1} \\
Y_{2 k}^{*}=\alpha_{2}+\beta_{2} X_{1}+\gamma Y_{1}+\mu_{2}
\end{array}\right.
$$

To properly identify the effects of working in environmentally registered firms on employee attitudes and behaviors, our econometric model includes 1) a set of detailed firm characteristics to control for managerial, productive and organizational practices and 2) both worker- and job-specific controls. Furthermore, for reasons of proper identification, this vector of exogenous regressors $X_{1}$ is restricted to be identical in both equations. It contains the following sets of exogenous variables:

- Firm characteristics: registration for quality standards such as ISO 9000 (QUALITY), use of just-in-time production methods (JIT), autonomous work groups (TEAM), degree of standardization of processes or working methods (STAND1-STAND4), size (SIZE) and dummies for the industry of the firm. 
- Workers' socio-demographic characteristics: gender (SEX), age and age squared ( $A G E$ and $A G E S Q$ ), marital status (SINGLE), level of education (EDU1-EDU5), seniority (SENIORITY) and occupational dummies (OCC1-OCC4 $)^{13}$.

- Job characteristics: the variables consist of part-time (PART-TIME), intensity of supervision (CONTROL1-CONTROL5), self-determination of working times (HD1-HD3), latitude to address incidents (INCIDENT) or interrupt the work at will (INTERRUPT), skill utilization (QUALIFICATION1), lack of required skills (QUALIFICATION2), workload (STRESS), normative demands in terms of targets (OBJECTIVE), precise instructions for task compliance $(H O W)$, task variety (REPETITION), safety consequences of worker mistakes (CONSEC), other consequences of worker mistakes (CONNEG), negative consequences of worker mistakes for the firm (CONFIR), information about required behavior (UNCLEAR), net hourly wage (WAGE), and the availability of help from colleagues and supervisor in case of work overload (HELPCOL and HELPCHEF $)^{14}$.

The vector of variable $Z_{1}$ represents the set of instrumental variables that usually guarantees the identification of the model and helps estimate the correlation coefficients (Maddala, 1983). According to Maddala, to identify the bivariate probit, we need at least one exclusion restriction, i.e., an additional instrumental variable, that explains the probability of working for a firm with environmental-related standards registration but that is not correlated with the usefulness, equitable recognition, job involvement and effort at work. However, Wilde (2000) states that in recursive bivariate probit models, each equation need only include one varying exogenous regressor to achieve identification. Actually, Monfardini and Radice (2008) clearly state that in the absence of an exclusion restriction, the quality of the inference derived from the Wald test of the estimated correlation coefficient between the error terms of the two equations strongly deteriorates.

\footnotetext{
13 These sets of firm and worker characteristics are usually used in the literature respectively as the determinants of the decision to adopt environmental-related standards (Grolleau et al., 2007b) and individuals' attitudes towards environmental-related issues (Torgler and Garcia-Valinas, 2007).

14 Considering the suspicion of colinearity between the job characteristics and the indicators of work organization, Pearson correlation coefficients were calculated and showed no evidence of partial correlation.
} 
Therefore, in our case, we included one variable that can play the role of instrument. Actually, our instrumental variable measures the firm's exports (EXPORT). In fact, a firm's environmental and ethical responsibility is frequently unobservable, especially when this firm intervenes on international markets. From a signaling perspective, the firms that have distant customers may choose to strategically implement institutional devices such as quality and environmental-related standards as this type of registration renders a firm's investments visible to the public and demonstrates the firm's contribution to satisfying the customers' quality and environmental expectations. Cao and Prakash (2011) show that the degree of trade competition increases the likelihood that firms join ISO 9000 standard while Bellesi et al. (2005) and King et al. (2006) illustrated how firms with potential foreign customers were more likely to registered with ISO 14001 standard. Moreover, as indicated by Grolleau et al. (2012), there should be no influence of exports on workers' attitudes and behavior. Additionally, even if there is a positive effect of working in an exporting firm on well-being and involvement at work, this effect will probably be captured by measures of worker's human capital and compensation since it has been shown that human capital intensity and average wages in exporting firms are higher than in non-exporting firms (e.g., Munch and Skaksen, 2008). Noteworthy, as indicated previously, we included variables measuring education levels, seniority and wage as control variables. ${ }^{15}$ Moreover, we checked for the interdependence between the variable EXPORT and indicators of employees' attitudes, job involvement and effort and found no evidence of partial correlation of colinearity (see Table of Pearson coefficients of correlation in Appendix 1).

$\beta_{1}, \beta_{2}, \gamma$ and $\delta$ are the slope coefficients, whereas $\alpha_{1}, \alpha_{2}, \mu_{1}$ and $\mu_{2}$ are the intercepts and the disturbance terms for the two equations, respectively. This set of coefficients is estimated using the Maximum Likelihood method.

The residuals of the two equations in (3) follow a normal bivariate law with zero means and a covariance matrix that can be written after the diagonal elements are normalized to 1 as follows:

$$
\left(\begin{array}{l}
\mu_{1} \\
\mu_{2}
\end{array}\right) \rightarrow N(0, \Sigma) \text {, where } \Sigma=\left(\begin{array}{cc}
1 & \rho_{12} \\
\rho_{21} & 1
\end{array}\right)
$$

\footnotetext{
15 Although it is not a proper test for the validity of the instrumental variables, it is worth noting that our proposed instrumental variable is not a significant determinant of employee attitudes, job involvement and work effort in a single equation probit model.
} 
In estimating the model, we find that a bivariate probit model produces an estimation of $\rho_{12}$, the correlation coefficient between the disturbance terms. When $\rho_{12}$ is significantly different from zero, a set of common unobserved factors simultaneously influences the employees' gains from working in a firm that is registered for an environmentally related standard and their attitudes, job involvement or level of effort. In other words, the variable for environmental-related standards is endogenous in the second equation of system (3) above. We test the significance of $\rho_{12}$ with a Wald chi-squared statistic.

\section{Results and discussion}

The results of the bivariate probit estimation are presented in Tables 2 and 3 along with the goodnessof-fit measures.

[Insert Tables 2 and 3 around here]

\section{Workers choice equation}

The results reported in Table 3 show that in the models explaining the employees' reported perception of usefulness, receipt of equitable recognition and compensation for working supplementary hours, $\rho_{12}$ is significantly different from 0 . This finding indicates that the unobservable explanatory factors of these attitudes and behavior are correlated with the use of environmental-related standards. Therefore, $Y_{1}$ is endogenous, which confirms the utility of the bivariate probit model. In contrast, $\rho_{12}$ is not significantly different from 0 in the employee job involvement model. Therefore, a simple univariate probit model in which $\rho_{12}$ is constrained to equal 0 would also provide unbiased results. Nevertheless, implementing the bivariate probit model was necessary to check for the exogeneity of this variable.

We present in Table 2 the estimation results regarding the factors that influence an employee's preference to work for an environmentally-related registered firm. The results are similar for all four models. We present the results obtained in conjunction with the estimation of the employees' reported perception regarding the usefulness of their jobs. 
We first notice that our instrumental variable export is positively associated to firm's probability to implement environmental-related standards. Then, among the firm characteristics, the use of the ISO 9000 quality standard, just-in-time production and autonomous work teams or groups have a positive and significant impact on the use of environmental-related standards. Previous experiences with similar processes and standards helped the organizations incur lower additional costs because of "learning-by-doing" (e.g., through the overlap of documentation) and scale economies (Grolleau et al., 2007a). Not surprisingly, if the standardization of production processes and working methods is not a strategically important issue for a firm, the likelihood of implementing environmental-related standards will decrease. Generally, the size of a firm's financial resources is the primary determinant of its likelihood of adopting environmental-related practices (e.g., Grolleau et al., 2007a). Our results imply that the larger the firm is, the more likely it is to adopt environmental-related standards. We also controlled for nine sectors of activities and defined a reference as the sector of trade (not reported in Tables 2 and 3). Similar to the literature, we find that the probability of adopting environmentalrelated practices is stronger in some industries, particularly the equipment, intermediate goods and energy sectors.

In term of the workers' socio-demographic characteristics, we notice that age, marital status and education have no influence on firm's probability to adopt environmental standards. Also, our results display some weak evidence that women are more attracted to firms registered with environmentalrelated standard than men, confirming previous findings that they have greater environmental concerns (e.g., Torgler and Garcia Valinas, 2007). On the other side, seniority is negatively associated with firm's decision to implement environmental standards. Furthermore, white-collar employees are more likely to work for firms that have registered for environmental-related standards than blue-collar employees. The other occupational categories have no effect on the probability of working for environmentally registered firms.

\section{Employees' attitudes, job involvement and effort equations}

The main goal of our study is to assess the influence of environmental-related standards on employee attitudes, job involvement and effort levels. The estimated effects of environmental-related standards 
on employees' reported attitude regarding the usefulness of their jobs and whether their work is equitably recognized, their job involvement and their effort levels are reported in Table 3 . The results display a mixed picture.

We find that the use of environmental-related standards positively impacts the employees' reported perception that their jobs are useful and that their work is equitably recognized. In fact, employees seem to appreciate working for a firm whose stance on environmental and social issues accords with their own feelings on these subjects. Hence, the choice of investing in environmental-related standards appears to have positive effects on workers' attitudes and motivation. The belief that one's job is useful to others is likely to fuel an employee's intrinsic motivation, while the reported perception of being equitably recognized prevents any disincentive effect created by the employee's aversion to inequity.

The argument that environmental-related standards improve job involvement and effort is only partially supported, as our results indicate that adherence to environmental-related standards has a positive but insignificant impact on job involvement. However, its positive impact on employee noncompensation for overtime hours suggests that employees' willingness to donate supplementary efforts is related to their environmental concerns. Based on this finding, we can interpret supplementary work effort as a type of labor donation.

Additionally, to evaluate the quantitative importance of the decision to implement environmentallyrelated standards, we can first assess its impact on the average employee in the population. In our case, this effect is computed as the difference between the probabilities that the employee with the average characteristics of the population reports a positive job attitude, job involvement and uncompensated effort at work when working in an environmentally registered firm and when working in a non-green firm. Furthermore, we also calculated the average treatment effects of environmental-related standards, which are evaluated as the difference between these probabilities averaged over the whole sample of employees. These average treatment effects measure the expected effects of working in a green firm for a randomly drawn individual from the whole population of workers. These figures are reported in the last two rows of Table 3. 
Our findings show that if the average worker were employed in an environmentally registered firm, he or she would have a probability higher by 7 and 3 percentage points to perceive his or her work useful and equitably recognized, respectively, than if he was employed in a non-green firm. Furthermore, although adherence to environmental-related standards does not significantly influence employees' self-reported levels of job involvement, it appears to increase the probability that the average worker does not receive any further compensation for his or her supplementary working hours by 4 Percentage points. The figures are larger for the evaluation of average treatment effects. In this case, the probability of perceiving that one's job is useful will increase by 11 percentage points, the probability that one is being equitably recognized will increase by 13 percentage points and the probability that one will not be compensated for overtime work will increase by 15 percentage points, for the workers employed in an environmental-related firm.

The differences between our two evaluation parameters are quite large but difficult to interpret. According to Meghir (2009), they represent two kinds of aggregation over different margins and as such are not directly comparable. The differences between our two evaluation parameters indicate nevertheless that the "average worker" of the population is probably unlikely to be a marginal worker as his observable gains to join an environmentally related firm are low compared with the average gains in the whole population. Hence, he would not join an environmentally registered firm except if he experienced very low (respectively high) unobservable costs (respectively benefits).

\section{Robustness of the results}

Several versions of the model have been estimated to investigate the robustness of these results. First, we have questioned the validity of our specification. More precisely, considering that large firms are known to be more generous on various aspects of compensation, we used different forms of the variable size (continuous form without logarithm and categorical form) and we obtained results that support the previous findings. Also, if we substitute logarithm of sales or assets for the size indicator, we obtain similar findings with in addition a positive and significant effect of environmental-related standards on the workers' job involvement. Additionally, we integrate in our model the firm's profit as an indicator of firm's economic performance and once again, the new results are consistent with 
previous ones. Finally, we questioned the sensitivity of our estimates to the choice of the explanatory job characteristics. Hence, several versions of the original model were estimated excluding alternatively the indicators of effort control, working time, workers' latitude and cooperation. All these robustness exercises confirm the positive influence of environmental-related standardization on the perception that one's job is useful, one is being equitably recognized and not compensated for overtime work.

Second, as workers with fixed term contract may choose to work harder to convince the managers to hire them permanently, we restricted the estimation of attitudes and behaviour to the set of workers with long term contracts and found no difference with our previous findings (see Appendix 2).

Third, we also questioned how our results are dependent on the choice of our instrumental variable. For that purpose, we included two dummy variables intended to measure to what extent the workers have chosen to participate in relational activities within the firm. The first dummy measures whether the worker joined a sport, cultural or social association within the firm while the second identifies the workers who chose not to join any of these associations. Finally, our reference group consists of the workers employed in the firms that do not have any of these associations. We argue that if the worker chose to take part in the activities of an association, then his or her behavior can be interpreted as an indication of his or her taste for involvement in social activities as it has been shown to be true in France (Prouteau and Wolff, 2004). The use of this supplementary instrumental variable does not affect our initial findings.

Finally, we wanted to take into account the likely correlations between our four dependant variables. Indeed, it is very likely that unobserved personality traits, like optimism for example, or preferences influence simultaneously the employees' attitudes to their jobs and behaviour at work. In the literature exploring the links between human resources management and various employees' outcomes, it is common practice to estimate these relationships independently. For example, Bockerman et al. (2012) estimates the effect of high involvement management on absenteeism, job satisfaction and pain felt at work independently. In contrary, we estimated the following simultaneous model: 


$$
\left\{\begin{array}{c}
Y_{1}^{*}=\alpha_{1}+\beta_{1} X_{1}+\delta Z_{1}+\mu_{1} \\
Y_{21}^{*}=\alpha_{21}+\beta_{21} X_{1}+\gamma_{1} Y_{1}+\mu_{2} \\
Y_{22}^{*}=\alpha_{22}+\beta_{22} X_{1}+\gamma_{2} Y_{1}+\mu_{3} \\
Y_{23}^{*}=\alpha_{23}+\beta_{23} X_{1}+\gamma_{3} Y_{1}+\mu_{4} \\
Y_{24}^{*}=\alpha_{24}+\beta_{24} X_{1}+\gamma_{4} Y_{1}+\mu_{5}
\end{array}\right.
$$

This model has a structure similar to that of a seemingly unrelated regression model (SUR), except that the dependent variables are binary indicators and that one endogenous variable $\left(Y_{1}^{*}\right.$ for STANDARD) appears as an explanatory variable in the rest of the model. Estimating such a model allows for a free correlation structure between the error terms of the four attitudes and behavior equations $\left(Y_{21}\right.$ to $\left.Y_{24}\right)$. Contrarily with a bivariate probit model like (3), this multivariate probit model (4) requires the application of a simulation method to maximum likelihood estimation. The method proposed by Cappellari and Jenkins (2003) uses the Geweke-Hajivassiliou-Keane (GHK) smooth recursive conditioning simulator. The estimated effects of environmental-related standards are compared with the estimates from the four independent biprobit models (3) in Table 4 below. Like all other robustness checks, the qualitative story told by the findings obtained from the "SUR" Mvprobit estimation remains unchanged, even if the four estimated error terms are significantly and positively correlated. The main difference is an attenuation of the increase of the probability that one is being equitably recognized when working for a "green” firm.

[Insert Table 4 around here]

Employee attitudes may channel the relationship between the environmental-related standards and the job involvement of employees

As our findings reveal that environmental-related standards have no direct influence on the degree of the employees' reported job involvement, we want to investigate whether there are specific channels through which adherence to environmental standards registration may indirectly impact the employees' job involvement. More precisely, as our results indicate that environmental-related standards are positively associated with employees' reported perception of usefulness and of being 
equitably recognized at work, we will try to understand whether these two indicators could act as significant stimulants of job involvement.

This alleged influence can be grounded in previous research in the organizational literature that has shown that positive employee feelings and emotions have positive effects on various employee outcomes, such as higher levels of task activity, work performance and job achievement (e.g., Staw et al., 1994). Though we are not aware of a direct test of the relationship between employees' beliefs in the utility of their jobs and the extent of their job involvement, previous research has studied the effect of public service motivation on employee attitudes and behavior at work. Public service motivation can be defined as an individual's motivation to help produce benefits for the interest of a community of people. Several studies have shown that when such motivation exists, both nonprofit and public sector employees are more involved in and efficient at their jobs (Moynihan and Pandey, 2007; Leisink and Steijn, 2009). We do not know of equivalent results in the private sector, but we hypothesize that private sector employees motivated by pro-social preferences may behave in a similar manner. Furthermore, the effect of fairness on employee commitment and effort has been empirically confirmed both in laboratory experiments and survey analyses (e.g., Meyer et al., 2002; Fehr and Schmidt, 2006; Fehr et al., 2009).

To verify empirically the role of employees' reported perceptions of usefulness and of being equitably recognized at work as indirect channels in the linkage between environmental-related standards and the employees' job involvement, we use a multivariate probit model. Similar to the bivariate probit model, the multivariate probit model relies on a simultaneous estimation approach in which the factors that determine the environmental-related standards registration, the employees' reported perception regarding the usefulness of their jobs or their reported perceptions of being equitably recognized are estimated simultaneously with the factors that explain the probability of high employee job involvement.

Compared with our previous bivariate model, in this model, we add a third equation in which the reported level of employees' job involvement $\left(Y_{23}\right)$ is explained by their reported perception about the 
usefulness of their jobs and their recognition at work, respectively $\left(Y_{21}\right.$ and $\left.Y_{22}\right)$. We consider the following multivariate probit model:

$$
\left\{\begin{array}{l}
Y_{1}^{*}=\alpha_{1}+\beta_{1} X_{1}+\delta Z_{1}+\mu_{1} \\
Y_{2 k}^{*}=\alpha_{2}+\beta_{2} X_{1}+\gamma Y_{1}+v Z_{2}+\mu_{2}, \quad k=1,2 \\
Y_{23}^{*}=\alpha_{3}+\beta_{3} X_{1}+\lambda Y_{2 k}+\mu_{3}
\end{array}\right.
$$

where $X_{1}$ and $Z_{1}$ represent the vector of exogenous variables and the set of instruments that we used previously in the bivariate probit model, respectively. Additionally, we include an instrumental variable $Z_{2}$ that explains the probability that an employee feels his or her work is useful and equitably recognized but should not be correlated to the error term of the employee's job involvement equation. For this purpose, we use the variable HANDICAP, which indicates whether the employee has a health problem or disability preventing him or her from holding certain work posts or performing certain tasks at work. This variable accounts for the fact that disabled employees are less likely to believe that they are useful to others and that they are equitably recognized (Stone and Colella, 1996). Moreover, it is argued that generally disabled employees are unfairly treated, including disparate opportunities for advancement (Braddock and Bachelder, 1994; Jones, 1997), more negative performance evaluations (Colella et al., 1997), even (arguably) differential rates of discharge. In the same vein, several authors underline that negative stereotypes about disabled employees influence unfair or undeserved treatment or doubtful status (Cleveland et al., 1997; Colella et al., 1997).Additionally, previous scholars have found that disability is linked to lower average pay, job security, training, participation in decisions (Schur et al., 2009). Therefore, as Schur et al. (2009) argued, "these differences contribute to the more negative evaluations of firm treatment by employees with disabilities, and their lower levels of company loyalty."

As for the bivariate probit model, we assume that the residuals in (4) are distributed as follows:

$$
\left(\begin{array}{l}
\mu_{1} \\
\mu_{2} \\
\mu_{3}
\end{array}\right) \rightarrow N(0, \Sigma) \text {, where } \Sigma=\left(\begin{array}{llc}
1 & \rho_{21} & \rho_{31} \\
\rho_{21} & 1 & \rho_{32} \\
\rho_{31} & \rho_{32} & 1
\end{array}\right)
$$


We will evaluate whether unobserved covariates jointly determine the outcomes of interest with a likelihood ratio (LR) test of the joint condition: $\rho_{21}=0, \rho_{31}=0$ and $\rho_{32}=0$. LR tests have been shown to be appropriate when testing for exogeneity while simultaneously estimating bivariate probit models (Monfardini and Radice, 2008). A similar reasoning is used here in the multivariate case.

\section{Results of the Multivariate Probit Model}

A summary of the results of the multivariate probit estimation is presented in Table 5. Our discussion will focus on the respective impacts of the employee's reported perception of being useful and equitably recognized on reported job involvement. Even if they are not reported in the table, we note that the effects of the control variables are similar to those obtained with the bivariate probit model. As expected, our instrumental variable HANDICAP negatively impacts the employees' reported perception of being useful and equitably recognized at work. ${ }^{16}$

[Insert Table 5 around here]

The main findings support the hypothesis that environmental-related standards indirectly affect employee job involvement through the channels of employees' reported perception of being useful and equitably recognized at work. Actually, the results indicate that there is a positive and statistically significant correlation between the employees' reported perception of usefulness at work and their job involvement (results summarized in Table 4, rows 2 and 3) as well as between the employees' reported perception of being equitably recognized at work and their job involvement (Table 4, rows 5 and 6). The calculations of the marginal effects show that the implementation of environmental-related standards raises the likelihood that the average employee feels that his or her job is useful to others by 9 percentage points. In turn, these reported perceptions raise the probability of being involved in the job by 24 percentage points. Also, the use of environmental-related standards raises the likelihood of perceiving his/her work equitably recognized by 3 percentage points, this last perception further improves the probability of being involved in the job by 9 percentage points. Based on these findings,

\footnotetext{
16 The results are available from the authors upon request.
} 
we bring to light two indirect mechanisms that permit environmental-related standards to enhance employee job involvement.

As previously, and in order to check if our results are dependent on the choice of instrumental variable, we perform robustness analysis using two different instrumental variables in replacement of the instrument HANDICAP. More precisely, as we can notice from Table 3 above, the variable INTERRUPT is significantly correlated with workers attitudes (USEFUL and RECOGNITION) but has no significant effect on the variable INVOLVEMENT. Therefore, we first use the variable INTERRUPT as an instrument. Then, we propose to use another variable EVALUATION indicating whether the employee carried out evaluation interviews as an evaluator in 2005 or 2006 as an instrument. The results of these robustness exercises can be read in the Appendices $3 \mathrm{a}$ and $3 \mathrm{~b}$ and confirm the qualitative reliability of our results. Noteworthy, the simulated estimations of our mvprobit models converge towards effects of equitable recognition and usefulness of the job on job involvement that vary respectively from 7 to 14 percentage points and from 22 to 26 percentage points with the chosen instrumental variable.

\section{Conclusion}

An increasing number of private firms are making considerable voluntary investments in environmental-related standards. One of the rationales for these implementations is that firms may anticipate savings on production costs and, more specifically, on labor costs. However, the previous evidence on this assumption only provided some indirect indications that firms may improve their abilities to recruit and motivate their workforce (e.g., Turban and Greening, 1997; Grolleau et al., 2012).

To fill a gap in the literature, this paper attempts to investigate the effect of environmental-related standards on three specific dimensions of human resource management. More precisely, using a representative employer-employee dataset of French private firms with more than 20 employees, we investigate the relationship between environmental-related standards and employee attitudes, involvement in the job and effort. The employees' attitudes are measured by their reported perception 
regarding their usefulness to others, their reported perception that their work is equitably recognized, while their job involvement and effort are respectively measured by the self-reported employees' involvement and the absence of compensation for supplementary work hours. Our estimation results unambiguously show that firms' registration for environmental-related standards is associated with higher reported perception of usefulness to others and reported perception of being equitably recognized among the employees. The findings related to job involvement suggest that, although employees do not claim to be significantly more involved in their jobs, "green workers" are more likely, ceteris paribus, to work uncompensated for supplementary work hours than non-green workers. Additionally, we test an alternative model in which the effects of the environmental-related standards on employee job involvement are conveyed through the employees' reported perception of usefulness to others and/or the employees' reported perception that their work is equitably recognized because the links between standards and employees attitudes have been well established. The results indicate that the employees' reported perception of usefulness to others and the employees' reported perception that their work is equitably recognized act as two indirect channels through which environmental-related standards enhance the employees' job involvement.

However, our study is only a first step toward an assessment of the labor productivity gains of environmental-related standards registration. Future research should develop supplementary indicators to assess the effects of environmental-related standards on absenteeism, health and safety issues and resignations. Such inquiries could shed new light on issues that might improve firms' overall business performance.

In addition, it will be important to provide direct empirical evidence of the association between labor cost reductions and the implementation of environmental-related standards. Another research avenue would be to study whether standardization has long-term benefits, beyond environmental performance, and helps green firms survive in competitive markets.

\section{References}

Akerlof, G.A., Kranton, R.E., 2005. Identity and the Economics of Organizations. Journal of Economic Perspectives 19, 9-32. 
Ambec, S., Lanoie, P., 2008. When and Why Does it Pay to be Green. Academy of Management Perspective 23, 45-62.

Appelbaum, E., Bailey, T., Berg, P., Kalleberg, A., 2000. Manufacturing Advantage: Why High Performance Work Systems Pay Off. ILR Press, Ithaca, N.Y.

Baron, V., 2005. Pratiquer le management de l'environnement : les réponses à vos questions. AFNOR, DL, Saint-Denis-La Plaine.

Bellesi, F., Lehrer, D., Tal, A., 2005. Comparative advantage: the impact of ISO 14001 environmental certification on exports. Environmental Science and Technology 39, 1943-1953.

Bénabou, R., Tirole, J., 2010. Individual and Corporate Social Responsibility. Economica 77, 1-19.

Benz, M., 2005. Not for the Profit but for the Satisfaction? Evidence on Worker Well-Being in Nonprofit Firms. Kyklos 58, 155-176.

Bewley, T., 2007. Fairness, Reciprocity and Wage Rigidity, in: Diamond, P.A., Vartiainen, H. (Eds.), Behavioral Economics and its Applications. Princeton University Press, pp.157-187.

DeBoer, E.M., Bakker, A.B., Syroit, J.E., Schaufeli, W.B., 2002. Unfairness at Work as a Predictor of Absenteeism. Journal of Organizational Behavior 23, 181-197.

Böckerman, P., Bryson, A., Ilmakunnas, P., 2012. Does high involvement management improve worker wellbeing? Journal of Economic Behavior \& Organization 84, 660- 680.

Braddock, D., Bachelder, L., 1994. The Glass Ceiling and Persons with Disabilities. Washington, DC: Glass Ceiling Commission, U.S. Department of Labor.

Brekke, K.A., Nyborg, K., 2008. Attracting Responsible Employees: Green Production as Labor Market Screening. Resource and Energy Economics 30(4), 509-526.

Bryson, A., Barth, E., Dale-Olsen, H., 2013. The Effects of Organizational Change on Worker WellBeing and the Moderating Role of Trade Unions. Industrial and Labor Relations Review 66, 9891011.

Cao, X., Prakash, A., 2011. Growing exports by signaling product quality: trade competition and the cross-national diffusion of ISO 9000 quality standards. Journal of Policy Analysis and Management 30(1), 111-135.

Cappellari, L., Jenkins, S.P., 2003. Multivariate probit regression using simulated maximum likelihood. Stata Journal 3(3), 278-294.

Cappelli, P., Rogovsky, N., 1998. Employee Involvement and Organizational Citizenship: Implications for Labor Law and Lean Production. Industrial and Labor Relations Review 51(4), 63353. 
Clark, A.E., 2010. Work, Jobs and Well-Being across the Millennium, in: Diener, E., Helliwell, J., Kahneman, D. (Eds.), International Differences in Well-Being. Oxford University Press, Oxford, pp. 436-468.

Cleveland, J.N., Barnes-Farrell, J.L., Ratz, J.M., 1997. Accommodation in the workplace. Human Resource Management Review 7(1), 77-107.

Colella, A., DeNisi, A., Varma, A., 1997. Appraising the performance of employees with disabilities: A review and model. Human Resource Management Review 7(1), 27-53.

Cottini, E., Kato, T., Westergaard-Nielsen, N., 2011. Adverse Workplace Conditions, HighInvolvement Work Practices and Labour Turnover: Evidence from Danish Linked EmployerEmployee Data. Labour Economics 18(6), 872-880.

Darnall, N., Henriques, I., Sadorsky, P., 2008. Do Environmental Management Systems Improve Business Performance in the International Setting? Journal of International Management 14(4), 364376.

Darnall, N., Sides, S. 2008. Assessing the performance of voluntary environmental programs: does certification matter? Policy Studies Journal 36(1), 95-117.

Delmas, M., Pekovic, S., 2012. Environmental Standards and Labor Productivity: Understanding the Mechanisms that Sustain Sustainability. Journal of Organizational Behavior 34(2), 230-252.

Diefendorff, J.M., Brown, D.J., Kamin, A.M., Lord, R.G., 2002. Examining the Roles of Job Involvement and Work Centrality in Predicting Organizational Citizenship Behaviors and Job Performance. Journal of Organizational Behavior 23(1), 93-108.

Donovan, M.A., Drasgow, F., Munson, L.J., 1998. The Perceptions of Fair Interpersonal Treatment scale: Development and Validation of a Measure of Interpersonal Treatment in the Workplace. Journal of Applied Psychology 83(5), 683-692.

Eagly, A.H., Chaiken, S., 1998. Attitude Structure and Function, in: Gilbert D.T., Fisk S.T., Lindsey G. (Eds.), Handbook of Social Psychology, New York: McGowan-Hill, pp. 269-322.

Ellemers, N., Spears, R., Doosje, B., 2002. Self and Social Identity. Annual Review of Psychology 53, 161-186.

Fehr, E., Goette, L., Zehnder, C., 2009. A Behavioural Account of the Labor Market: the Role of Fairness Concerns. Annual Review of Economics 1, 355-384.

Fehr, E., Schmidt, K.M., 2006. The Economics of Fairness, Reciprocity and Altruism. Experimental Evidence and New Theories, in: Kolm, S.C., Mercier Ythier, J. (Eds.), Handbook on the Economics of Giving, Reciprocity and Altruism. North-Holland, pp. 615-691.

Frank, R.H., 1996. What Price the Moral High Ground? Southern Economic Journal 63(1), 1-17. 
Freeman, R.E., 1984. Strategic management: a stakeholder approach. Pitman Publishing, Marshfield.

Godard, J., 2010. What is best for workers? The implications of workplace and human resource management practices revisited. Industrial Relations 49, 466-488.

Green, F., 2004. Why has work effort become more intense? Industrial Relations 43, 709-741.

Gregg, P., Grout, P., Ratcliffe, A., Smith, S., Windmeijer, F., 2011. How Important is Pro-Social Behaviour in the Delivery of Public Services? Journal of Public Economics 95,758-766.

Grolleau, G., Mzoughi, N., Pekovic, S., 2007a. Chemical Firms' Registration for the Responsible Care Program and the ISO 14001 Standard: A Comparative Approach. Economic Bulletin 12(29), 1-13.

Grolleau, G., Mzoughi, N., Thomas, A., 2007b. What Drives Agrifood Firms to Register for an Environmental Management System? European review of Agricultural Economics 34, 233-255.

Grolleau, G., Mzoughi, N., Pekovic, S., 2012. Green Not (only) for Profit: An Empirical Examination of the Effect of Environmental-Related Standards on Employees' Recruitment. Resource and Energy Economics 34(1), 74-92.

Haslam, A.S., 2001. Psychology in Organizations: The Social Identity Approach. Thousand Oaks, Calif.: Sage Publications.

Heckman, J.J., Vytlacil, E., 2005. Structural Equations, Treatment Effects, And Econometric Policy Evaluation. Econometrica 73, 669-738.

Jones, G.E., 1997. Advancement opportunities issues for persons with disabilities. Human Resource Management Review 7(1), 55-76.

Khanna, M., Anton, W.R.Q., 2002. Corporate Environmental Management: Regulatory and Market Based Incentives. Land Economics 78, 539-558.

King A.A., Lennox, M.J., Terlaak, A., 2006. The strategic use of decentralized institutions: exploring certification with the ISO 14001 management standard. Academy of Management Journal 48(6), 1091-1106.

Lanfranchi, J., Narcy, M., 2008. Différence de satisfaction dans l'emploi entre les secteurs à but lucratif et à but non lucratif: le rôle joué par les caractéristiques d'emploi. Annals of Public and Cooperative Economics 79(2), 323-368.

Lanfranchi, J., Narcy, M., 2010. Wages and Effort in The French For-Profit and Nonprofit Sectors: The Labor Donation Theory Revisited. Working Paper LEMMA, Université Panthéon Assas.

Lannelongue, G., Gonzalez-Benito, J., 2012. Opportunism and environmental management systems: Certification as a smokescreen for stakeholders. Ecological Economics 82, 11-22 
Leisink, P., Steijn, B., 2009. Public Service Motivation and Job Performance of Public Sector Employees in the Netherlands. International Review of Administrative Sciences 75(1), 35-52.

Locke, E.A., 1976. The Nature and Causes of Job Satisfaction, in: Dunnette, M.D. (Ed.), Handbook of Industrial and Organizational Psychology. IL, Rand-McNally, Chicago, pp.1297-1349.

Lodahl, T.M., Kejner, M., 1965. The Definition and Measurement of Job Involvement. Journal of Applied Psychology 49, 24-33.

Maddala, G.S., 1983. Limited-Dependent and Qualitative Variables in Econometrics. Cambridge University Press, Cambridge, England.

Meghir, C., 2009. Marginal Treatment Effects and the Relationship between Evaluation Parameters. Labour Lectures n ${ }^{\circ}$, Einaudi Institute for Economics and Finance.

Meyer, J.P., Stanley, D.J., Herscovitch, L., Topolnytsky, L., 2002. Affective, Continuance, and Normative Commitment to the Organization: A Meta-Analysis of Antecedents, Correlates, and Consequences. Journal of Vocational Behavior 61, 20-52.

Michael, J.H., Evans, D.D., Jansen, K., Haight, J., 2005. Management Commitment to Safety as Organizational Support: Relationships with Non-Safety Outcomes in Wood Manufacturing. Journal of Safety Research 36, 171-179.

Monfardini, C., Radice, R., 2008. Testing Exogeneity in the Bivariate Probit Model: A Monte Carlo Study. Oxford Bulletin of Economics and Statistics 70, 271-282.

Moynihan, D.P., Pandey, S.K., 2007. Finding Workable Levers over Work Motivation: Comparing Job Satisfaction, Job Involvement and Organizational Commitment. Administration and Society 39(7), 803-832.

Munch, J.R., Skaksen, J.R., 2008. Human Capital and Wages in Exporting Firms. Journal of International Economics 75, 363-372.

Narcy, M., 2011. Would Nonprofit Workers Accept to Earn Less? Evidence from France. Applied Economics 43(3), 313-326.

Nishitani, K., 2009. An empirical study of the initial adoption of ISO 14001 in Japanese manufacturing firms. Environmental Economics 68, 669-679.

Porter, M., Van Der Linde, C., 1995. Toward a New Conception of the Environment-Competitiveness Relationship. Journal of Economic Perspectives 9(4), 97-118.

Preston, A.E., 1989. The Nonprofit Worker in a For-profit World. Journal of Labor Economics 7(4), 438-463. 
Prouteau, L., Wolff , F.-C., 2004. Donner son temps: les bénévoles dans la vie associative. Economie et Statistique 372, 3-39.

Schur, L., Kruse, D., Blasi, J., Blank, P., 2009. Is Disability Disabling in All Workplaces? Workplace Disparities and Corporate Culture. Industrial Relations 48(3), 381-410.

Sousa-Poza, A., Sousa-Poza, A.A., 2000, Well-being at work: a cross-national analysis of the levels and determinants of job satisfaction. Journal of Socio-Economics 29: 517-538.

Staw, B.M., Sutton, R.I., Pelled, L.H., 1994. Employee Positive Emotion and Favorable Outcomes at the Workplace. Organization Science 5, 51-71.

Stone, D.L., Collela, A., 1996. A Model of Factors Affecting the Treatment of Disabled Individuals in Organizations. The Academy of Management Review 21(2), 352-401.

Takaki, J., Tsutsumi, A., Irimaji, H., Hayama, A., Hibino, Y., Kanbara, S., Sakano, N., Ogino, K., 2010. Possible Health-Protecting Effects of Feeling Useful to Others on Symptoms of Depression and Sleep Disturbance in the Workplace. Journal of Occupational Health 52, 287-293.

Torgler, B., Garcia-Valinas, M.A., 2007. The Determinants of Individuals' Attitudes towards Preventing Environmental Damage. Ecological Economics 63, 536-552.

Turban, D., Greening, D., 1997. Corporate Social Performance and Organizational Attractiveness to Prospective Employees. Academy of Management Journal 40, 658-672.

Van Vegchel, N., de Jonge, J., Bosma, H., Schaufeli, W., 2005. Reviewing the Effort-Reward Imbalance Model: Drawing up the Balance of 45 Empirical Studies. Social Science \& Medicine 60, $1117-1131$.

Warr, P.B., 2007. Work, Happiness, and Unhappiness. New York: Routledge.

Wilde, J., 2000. Identification of Multiple Equation Probit Models with Endogenous Dummy Regressors. Economics Letters 69, 309-312. 
Table 1. Definition of variables and sample statistics

\begin{tabular}{|c|c|c|c|}
\hline Variable & Definition & $\begin{array}{l}\text { Mean } \\
\text { (SD) }\end{array}$ & $\begin{array}{l}\text { Weighted } \\
\text { mean }\end{array}$ \\
\hline \multicolumn{4}{|l|}{ Dependent variables } \\
\hline USEFUL & $\begin{array}{l}\text { The employee's work is useful to others } \\
\text { Dummy variable ( }=1 \text { if yes) }\end{array}$ & 0.90 & 0.91 \\
\hline RECOGNITION & $\begin{array}{l}\text { The employee's work is equitably recognized } \\
\text { Dummy variable (=1 if yes) }\end{array}$ & 0.43 & 0.44 \\
\hline INVOLVEMENT & $\begin{array}{l}\text { The employee is involved in his work } \\
\text { Dummy variable }(=1 \text { if employee is very } \\
\text { involved })\end{array}$ & 0.69 & 0.69 \\
\hline $\begin{array}{l}\text { NON } \\
\text { COMPENSATED } \\
\text { OVERTIMES }\end{array}$ & $\begin{array}{l}\text { The employee is not compensated for } \\
\text { supplementary work hours } \\
\text { Dummy variable (=1 if yes) }\end{array}$ & 0.53 & 0.52 \\
\hline \multicolumn{4}{|c|}{ Independent variables } \\
\hline STANDARDS $^{*}$ & $\begin{array}{l}\text { The employee works for a firm registered for ISO } \\
14000 \text {, organic labeling or fair trade } \\
\text { Dummy variable (=1 if registered in 2006) }\end{array}$ & 0.29 & 0.34 \\
\hline QUALITY & $\begin{array}{l}\text { The employee works for a firm registered for ISO } \\
9000 \text {, EAQF (Supplier Quality capability } \\
\text { evaluation), etc. } \\
\text { Dummy variable (=1 if registered in 2006) }\end{array}$ & 0.60 & 0.62 \\
\hline JIT & $\begin{array}{l}\text { The firm utilizes just-in-time methods } \\
\text { Dummy variable ( }=1 \text { if registered in } 2006 \text { ) }\end{array}$ & 0.37 & 0.41 \\
\hline TEAM & $\begin{array}{l}\text { The firm utilizes autonomous work groups or } \\
\text { teams } \\
\text { Dummy variable (=1 if registered in 2006) }\end{array}$ & 0.50 & 0.53 \\
\hline STAND & $\begin{array}{l}\text { The strategic importance of the standardization of } \\
\text { processes and working methods is: } \\
\text { STAND1 (very important) (ref) } \\
\text { STAND2 (important) } \\
\text { STAND3 (quite important) } \\
\text { STAND4 (not important) }\end{array}$ & $\begin{array}{c}0.17 \\
0.59 \\
0.22 \\
0.023\end{array}$ & $\begin{array}{r}0.20 \\
0.58 \\
0.20 \\
0.021\end{array}$ \\
\hline SIZE & $\begin{array}{l}\text { Logarithm of number of employees } \\
\text { (Continuous variable) }\end{array}$ & 5.70 & 6.30 \\
\hline EXPORT & $\begin{array}{l}\text { The export volume }(€) \\
\text { (Continuous variable) }\end{array}$ & $\begin{array}{l}111865 \\
(10244)\end{array}$ & $\begin{array}{c}818,762 \\
(496623)\end{array}$ \\
\hline SEX & $\begin{array}{l}\text { The employee is a woman } \\
\text { Dummy variable ( }=1 \text { if yes) }\end{array}$ & 0.36 & 0.32 \\
\hline AGE & $\begin{array}{l}\text { Age } \\
\text { (Continuous variable) }\end{array}$ & $\begin{array}{c}39.80 \\
(0.093)\end{array}$ & $\begin{array}{c}40.20 \\
(0.149)\end{array}$ \\
\hline AGESQ & $\begin{array}{l}\text { Age Squared } \\
\text { (Continuous variable) }\end{array}$ & $\begin{array}{c}1683 \\
(7.45)\end{array}$ & $\begin{array}{c}1716 \\
(12.37)\end{array}$ \\
\hline SINGLE & $\begin{array}{l}\text { The employee lives alone } \\
\text { Dummy variable (=1 if yes) }\end{array}$ & 0.24 & 0.24 \\
\hline EDUCATION & $\begin{array}{l}\text { Employee has: } \\
\text { EDU1 (primary or lower secondary degree) } \\
\text { EDU2 (technical degree) }(\boldsymbol{r} \boldsymbol{e} \text { ) } \\
\text { EDU3 (general secondary or preparation for }\end{array}$ & $\begin{array}{l}0.13 \\
0.40\end{array}$ & $\begin{array}{l}0.13 \\
0.39\end{array}$ \\
\hline
\end{tabular}




\begin{tabular}{|c|c|c|c|}
\hline & specialized secondary degree) & 0.18 & 0.18 \\
\hline & EDU4 (superior-fist cycle degree) & & \\
\hline & EDU5 (superior-first or second cycle degree, & 0.17 & 0.17 \\
\hline & grande école, école de commerce, etc.) & 0.12 & 0.13 \\
\hline \multirow[t]{2}{*}{ SENIORITY } & Number of years of seniority in the firm & 12.46 & 12.59 \\
\hline & (Continuous variable) & $(0.092)$ & $(0.245)$ \\
\hline \multirow[t]{5}{*}{ OCCUPATION } & Employee is: & & \\
\hline & OCC1 (management) & 0.12 & 0.14 \\
\hline & OCC2 (middle-management) & 0.24 & 0.24 \\
\hline & OCC3 (white collar workers) & 0.19 & 0.19 \\
\hline & OCC4 (blue collar workers) (ref) & 0.45 & 0.43 \\
\hline \multirow[t]{4}{*}{ HANDICAP } & The employee has a health problem or disability & 0.08 & 0.208 \\
\hline & preventing him or her from holding certain work & & \\
\hline & posts or performing certain tasks at work & & \\
\hline & Dummy variable (=1 if yes) & & \\
\hline \multirow{2}{*}{ PART-TIME } & The employee has a part-time job & 0.08 & 0.08 \\
\hline & Dummy variable (=1 if yes) & & \\
\hline \multirow[t]{6}{*}{ CONTROL } & The employee's work is controlled: & & \\
\hline & CONTROL1 (if controlled constantly) & 0.22 & 0.22 \\
\hline & CONTROL2 (if controlled at least once a day) & 0.15 & 0.16 \\
\hline & CONTROL3 (if controlled at least once a week) & 0.14 & 0.15 \\
\hline & CONTROL4 (if controlled at least once a month) & 0.10 & 0.09 \\
\hline & $\begin{array}{l}\text { CONTROL5 (if controlled for occasionally, rarely } \\
\text { or never) (ref) }\end{array}$ & 0.39 & 0.38 \\
\hline \multirow[t]{4}{*}{ HDETER } & Working times are defined: & & \\
\hline & $\begin{array}{l}\text { HD1 (if defined by a firm without a possibility of } \\
\text { modification) }\end{array}$ & 0.66 & 0.5 \\
\hline & $\begin{array}{l}\text { HD2 (possibility of choosing between different } \\
\text { working hours) }\end{array}$ & 0.20 & 0.20 \\
\hline & HD3 (if defined by employee) (ref) & 0.14 & 0.175 \\
\hline \multirow{2}{*}{ INCIDENT } & The employee must address incidents alone & 0.49 & 0.49 \\
\hline & Dummy variable (=1 if yes ) & & \\
\hline \multirow{3}{*}{ INTERRUPT } & The employee cannot interrupt his or her work for & 0.18 & 0.18 \\
\hline & a moment if he or she wishes & & \\
\hline & Dummy variable (=1 if yes) & & \\
\hline \multirow{3}{*}{ QUALIFICATION1 } & The employee thinks that he or she lacks certain & 0.40 & 0.41 \\
\hline & skills to do his or her job correctly & & \\
\hline & Dummy variable (=1 if yes) & & \\
\hline \multirow{3}{*}{ QUALIFICATION2 } & The employee does not use all of his or her skills & 0.49 & 0.50 \\
\hline & in his or her job & & \\
\hline & Dummy variable (=1 if yes) & & \\
\hline \multirow{4}{*}{ STRESS } & The employee feels unable to cope with his or her & 0.549 & 0.49 \\
\hline & work or is overloaded every day, at least once a & & \\
\hline & week or at least once a month & & \\
\hline & Dummy variable (=1 if yes) & & \\
\hline \multirow{2}{*}{ OBJECTIVE } & The employee must reach precise targets & 0.60 & 0.61 \\
\hline & Dummy variable (=1 if yes) & & \\
\hline HOW & $\begin{array}{l}\text { The employee receives precise instructions on } \\
\text { how he or she should realize his or her task }\end{array}$ & 0.22 & 0.222 \\
\hline
\end{tabular}




\begin{tabular}{|c|c|c|c|}
\hline & Dummy variable (=1 if yes) & & \\
\hline REPETITION & $\begin{array}{l}\text { The employee almost never or never realizes } \\
\text { different tasks } \\
\text { Dummy variable ( }=1 \text { if almost never or never) }\end{array}$ & 0.27 & 0.27 \\
\hline CONSEC & $\begin{array}{l}\text { The employee's mistake can provoke direct } \\
\text { dangerous consequences for his/her or others' } \\
\text { security } \\
\text { Dummy variable (=1 if yes) }\end{array}$ & 0.49 & 0.49 \\
\hline CONNEG & $\begin{array}{l}\text { The employee's mistake can provoke other direct } \\
\text { negative consequences (e.g., sanction, loss of } \\
\text { wage, dismissal, loss of performance bonus, and } \\
\text { impact on the quality of colleagues' work) for } \\
\text { himself/herself or other employees } \\
\text { Dummy variable (=1 if yes) }\end{array}$ & 0.54 & 0.54 \\
\hline CONFIR & $\begin{array}{l}\text { The employee's mistake can provoke negative } \\
\text { consequences for the firm (e.g., financial } \\
\text { consequences, negative image, and loss of clients) } \\
\text { Dummy variable (=1 if yes) }\end{array}$ & 0.27 & 0.28 \\
\hline UNCLEAR & $\begin{array}{l}\text { The employee has not been clearly told what he or } \\
\text { she must do in his or her job } \\
\text { Dummy variable (=1 if yes) }\end{array}$ & 0.33 & 0.33 \\
\hline HELPCHEF & $\begin{array}{l}\text { The employee will be helped by his or her } \\
\text { superior if he or she is overloaded with work } \\
\text { Dummy variable ( }=1 \text { if yes) }\end{array}$ & 0.43 & 0.44 \\
\hline HELPCOL & $\begin{array}{l}\text { The employee will be helped by his or her } \\
\text { colleagues if he or she is overloaded with work } \\
\text { Dummy variable ( }=1 \text { if yes) }\end{array}$ & 0.75 & 0.74 \\
\hline FAMILIAR & $\begin{array}{l}\text { The employee uses the familiar "tu" when } \\
\text { speaking to his or her superior } \\
\text { Dummy variable (=1 if yes) }\end{array}$ & 0.35 & 0.34 \\
\hline WAGE & $\begin{array}{l}\text { Net hourly wage } \\
\text { (Continuous variable) }\end{array}$ & $\begin{array}{r}8.97 \\
(0.08) \\
\end{array}$ & $\begin{array}{c}9.74 \\
(0.51)\end{array}$ \\
\hline HANDICAP & $\begin{array}{l}\text { The employee has a health problem or disability } \\
\text { preventing him or her from holding certain work } \\
\text { posts or performing certain tasks at work } \\
\text { Dummy variable (=1 if yes) }\end{array}$ & 0.08 & 0.08 \\
\hline EVALUATION & $\begin{array}{l}\text { The employee carried out evaluation interviews as } \\
\text { an evaluator in the last two years } \\
\text { Dummy variable (=1 if yes) }\end{array}$ & 0.10 & 0.11 \\
\hline $\begin{array}{l}\text { ACTIVITY } \\
\text { (for space reasons, } \\
\text { we do not report the } \\
\text { sample statistics for } \\
\text { these variables) }\end{array}$ & $\begin{array}{l}\text { The main activity of the firm (based on } 9 \text { inc } \\
\text { consumption goods, intermediate goods and energy } \\
\text { construction, financial and real-estate activities, } \\
\text { services for firms and media, transport }\end{array}$ & $\begin{array}{l}\text { try dur } \\
\text { quipme } \\
\text { ro-alim }\end{array}$ & $\begin{array}{l}\text { variables): } \\
\text { ds, trade, } \\
\text { industry, }\end{array}$ \\
\hline $\mathrm{N}$ & & 11,602 & 109,906 \\
\hline
\end{tabular}


Table 2. Bivariate probit estimates of the determinants of the probability for an employee to work in an environmentally registered firm

\begin{tabular}{|c|c|c|c|}
\hline & & \multicolumn{2}{|c|}{ STANDARDS } \\
\hline & & Estimate & Standard Errors \\
\hline \multicolumn{4}{|l|}{ Variables } \\
\hline Intercept & & $7.21 *$ & 4.14 \\
\hline STANDARD & & - & - \\
\hline QUALITY & & $1.09 * * *$ & 0.04 \\
\hline JIT & & $0.27 * * *$ & 0.03 \\
\hline TEAM & & $0.26^{* * *}$ & 0.03 \\
\hline \multirow{3}{*}{ STAND } & STAND2 & -0.03 & 0.04 \\
\hline & STAND3 & -0.05 & 0.05 \\
\hline & $\begin{array}{l}\text { STAND4 } \\
\text { STA }\end{array}$ & $-0.25^{* *}$ & 0.13 \\
\hline SIZE & & $0.20 * * *$ & 0.01 \\
\hline EXPORT & & $4.9010^{-7} * * *$ & $7.98 \mathrm{e}-08$ \\
\hline SEXE & & 0.06 & 0.04 \\
\hline AGE & & -0.00 & 0.01 \\
\hline AGESQ & & 0.00 & 0.00 \\
\hline SINGLE & & -0.02 & 0.03 \\
\hline \multirow{4}{*}{ EDUCATION } & EDU1 & -0.05 & 0.05 \\
\hline & EDU3 & -0.05 & 0.04 \\
\hline & EDU4 & -0.00 & 0.05 \\
\hline & EDU5 & 0.05 & 0.06 \\
\hline SENIORITY & & $0.005^{* * *}$ & 0.00 \\
\hline \multirow{3}{*}{ OCCUPATION } & OCC1 & -0.00 & 0.07 \\
\hline & OCC2 & 0.06 & 0.04 \\
\hline & OCC3 & $0.22 * * *$ & 0.05 \\
\hline \multirow{4}{*}{ CONTROL } & CONTROL1 & 0.04 & 0.04 \\
\hline & CONTROL2 & 0.03 & 0.04 \\
\hline & CONTROL3 & 0.00 & 0.05 \\
\hline & CONTROL4 & -0.02 & 0.05 \\
\hline \multirow{2}{*}{ HDETER } & HD1 & 0.04 & 0.05 \\
\hline & HD2 & 0.01 & 0.05 \\
\hline PART-TIME & & 0.05 & 0.06 \\
\hline CONSEC & & -0.00 & 0.03 \\
\hline
\end{tabular}




\begin{tabular}{lll}
\hline CONNEG & $0.06^{*}$ & 0.04 \\
\hline CONFIR & 0.00 & 0.04 \\
\hline UNCLEAR & $-0.05^{*}$ & 0.03 \\
\hline REPETITION & 0.05 & 0.03 \\
\hline OBJECTIVE & 0.05 & 0.03 \\
\hline HOW & -0.00 & 0.04 \\
\hline STRESS & $-0.07^{* * *}$ & 0.03 \\
\hline FAMILIAR & -0.00 & 0.03 \\
\hline INCIDENT & 0.03 & 0.03 \\
\hline INTERRUPT & 0.01 & 0.04 \\
\hline QUALIFICATION1 & -0.01 & 0.03 \\
\hline QUALIFICATION2 & -0.02 & 0.03 \\
\hline HELPCHEF & 0.05 & 0.03 \\
\hline HELPCOL & 0.03 & 0.04 \\
\hline WAGE & $-0.00 *$ & 0.00
\end{tabular}

$(*),(* *),(* * *)$ indicate parameter significance at the 10,5 and 1 percent levels, respectively. Dummies for nine industries are included in both regressions but not reported for space reasons. 
Table 3. Bivariate probit estimates of the effect of environmental standards on employee's attitudes, job involvement and effort

\begin{tabular}{|c|c|c|c|c|c|c|c|c|c|}
\hline & \multicolumn{3}{|c|}{ USEFUL } & \multicolumn{2}{|c|}{ RECOGNITION } & \multicolumn{2}{|c|}{ INVOLVEMENT } & \multicolumn{2}{|c|}{$\begin{array}{l}\text { NON COMPENSATED } \\
\text { OVERTIMES }\end{array}$} \\
\hline \multicolumn{2}{|l|}{ Variables } & Estimate & SE & Estimate & SE & Estimate & SE & Estimate & SE \\
\hline \multicolumn{2}{|l|}{ Intercept } & 1.23 & 4.75 & $-0.15 * * *$ & 3.43 & $-9.41 * * *$ & 3.57 & 0.24 & 3.41 \\
\hline \multicolumn{2}{|l|}{ STANDARD } & $0.75^{* * *}$ & 0.32 & $0.37 * * *$ & 0.13 & 0.25 & 0.16 & $0.40 * * *$ & 0.15 \\
\hline \multicolumn{2}{|l|}{ QUALITY } & -0.14 & 0.12 & $-0.08 *$ & 0.04 & $-0.09 *$ & 0.05 & -0.02 & 0.15 \\
\hline \multicolumn{2}{|l|}{ JIT } & -0.02 & 0.05 & $-0.05^{*}$ & 0.03 & 0.00 & 0.03 & $-0.10 * * *$ & 0.03 \\
\hline \multicolumn{2}{|l|}{ TEAM } & $-0.12 * * *$ & 0.04 & -0.02 & 0.03 & -0.01 & 0.03 & 0.02 & 0.03 \\
\hline \multirow{3}{*}{ STAND } & STAND2 & -0.02 & 0.04 & 0.00 & 0.03 & 0.01 & 0.03 & 0.03 & 0.03 \\
\hline & $\begin{array}{l}\text { STAND3 } \\
\text { STA }\end{array}$ & 0.02 & 0.05 & -0.04 & 0.04 & 0.03 & 0.04 & 0.06 & 0.04 \\
\hline & STAND4 & -0.11 & 0.11 & -0.04 & 0.09 & $0.17 *$ & 0.09 & -0.03 & 0.08 \\
\hline \multicolumn{2}{|l|}{ SIZE } & $-0.04 *$ & 0.02 & $-0.03 * * *$ & 0.01 & $-0.03 * *$ & 0.01 & -0.01 & 0.01 \\
\hline \multicolumn{2}{|l|}{ SEXE } & $-0.11 * * *$ & 0.04 & $-0.21 * * *$ & 0.03 & $0.13^{* * *}$ & 0.03 & $0.08 * * *$ & 0.03 \\
\hline \multicolumn{2}{|l|}{$\mathrm{AGE}$} & 0.01 & 0.01 & -0.01 & 0.01 & 0.01 & 0.01 & -0.01 & 0.01 \\
\hline \multicolumn{2}{|l|}{ AGESQ } & -0.00 & 0.00 & 0.00 & 0.00 & -0.00 & 0.00 & $0.00 *$ & 0.00 \\
\hline \multicolumn{2}{|l|}{ SINGLE } & -0.03 & 0.04 & -0.03 & 0.03 & -0.04 & 0.03 & 0.02 & 0.03 \\
\hline \multirow{4}{*}{ EDUCATION } & EDU1 & $-0.14 * * *$ & 0.05 & -0.01 & 0.04 & 0.01 & 0.04 & $0.11 * * *$ & 0.04 \\
\hline & EDU3 & 0.02 & 0.05 & -0.05 & 0.04 & 0.05 & 0.04 & 0.02 & 0.03 \\
\hline & $\overline{\text { EDU4 }}$ & $0.11 * *$ & 0.06 & $0.08 *$ & 0.04 & $0.07 *$ & 0.04 & 0.06 & 0.04 \\
\hline & EDU5 & 0.06 & 0.07 & 0.07 & 0.05 & 0.03 & 0.06 & $0.14 * * *$ & 0.05 \\
\hline \multicolumn{2}{|l|}{ SENIORITY } & 0.001 & 0.00 & $-0.009 * * *$ & 0.00 & $-0.05 * * *$ & 0.00 & $-0.003 * *$ & 0.00 \\
\hline \multirow{3}{*}{ OCCUPATION } & OCC1 & 0.12 & 0.08 & $0.44 * * *$ & 0.06 & $0.51 * * *$ & 0.06 & $0.56^{* * * *}$ & 0.06 \\
\hline & OCC2 & $0.17 * * *$ & 0.05 & $0.20 * * *$ & 0.04 & $0.32 * * *$ & 0.04 & $0.16^{* * *}$ & 0.04 \\
\hline & OCC3 & 0.09 & 0.06 & 0.01 & 0.04 & $0.16^{* * *}$ & 0.04 & 0.05 & 0.04 \\
\hline \multirow{4}{*}{ CONTROL } & CONTROL1 & $-0.08 *$ & 0.04 & $-0.13 * * *$ & 0.03 & -0.03 & 0.03 & -0.03 & 0.03 \\
\hline & $\begin{array}{l}\text { CONTROL2 } \\
\text { CONR }\end{array}$ & $-0.10 * *$ & 0.05 & -0.03 & 0.04 & $-0.09 * * *$ & 0.04 & -0.02 & 0.04 \\
\hline & CONTROL3 & 0.00 & 0.05 & -0.03 & 0.04 & -0.01 & 0.04 & 0.01 & 0.04 \\
\hline & CONTROLA & 0.05 & 0.06 & -0.03 & 0.04 & -0.02 & 0.05 & 0.01 & 0.04 \\
\hline
\end{tabular}




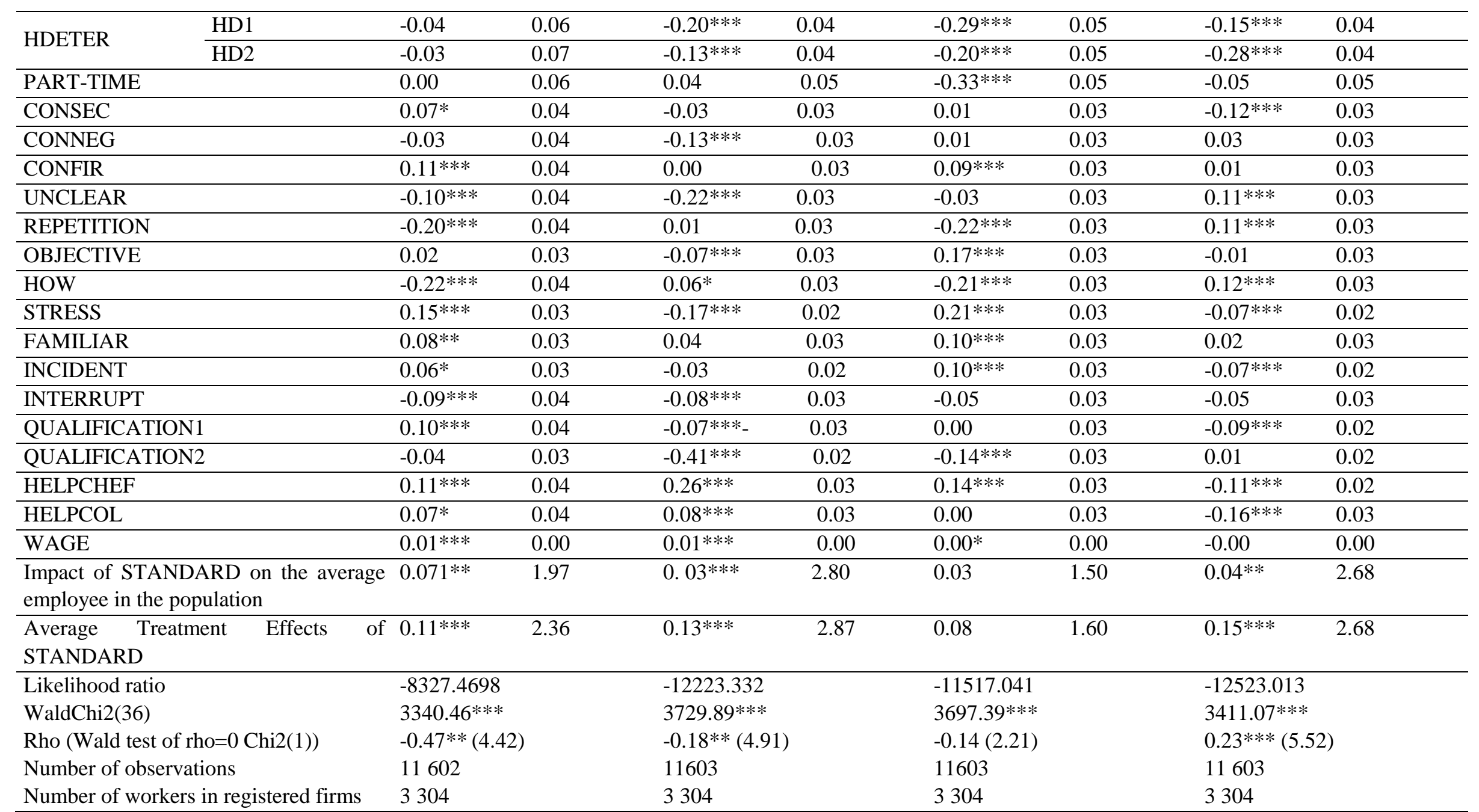

$(*),(* *),(* * *)$ indicate parameter significance at the 10,5 and 1 percent levels, respectively. Dummies for nine industries are included in both regressions but not reported for space reasons. Estimation of the variance of coefficients is robust to the fact that the error term is not identically distributed.

The reported impacts of STANDARD are computed for the average worker of the population and the respective standard errors are evaluated with the delta method. The average treatment effects and standard errors are computed using a bootstrap with 500 simulations. 
Table 4. Bivariate probit and multivariate probit estimates of the impact on the average employee and the average treatment effect of Environmental-related standards

USEFUL RECOGNITION INVOLVEMENT NON COMPENSATED
OVERTIMES

\begin{tabular}{llllc}
\hline $\begin{array}{l}\text { Impact of STANDARD for the } \\
\text { average employee (Biprobit) }\end{array}$ & $0.071^{* *}$ & $0.03^{* * *}$ & 0.03 & $0.04^{* * *}$ \\
\hline $\begin{array}{l}\text { Impact of STANDARD for the } \\
\text { average employee (Mvprobit) }\end{array}$ & $0.069^{* *}$ & $0.023^{* *}$ & 0.016 & $0.042^{* * *}$ \\
\hline $\begin{array}{l}\text { Average Treatment effect } \\
\text { (Biprobit) }\end{array}$ & $0.11^{* * *}$ & $0.13^{* * *}$ & 0.08 & $0.15^{* * *}$ \\
\hline $\begin{array}{l}\text { Average Treatment effect } \\
\text { (Mvprobit) }\end{array}$ & $0.103^{* * *}$ & $0.096^{* * *}$ & 0.051 & $0.154^{* * *}$ \\
\hline
\end{tabular}

$(*),(* *),(* * *)$ indicate parameter significance at the 10,5 and 1 percent levels, respectively.

Table 5. Multivariate probit estimates of the relationship between environmental standards, employee's attitudes toward job and employee's job involvement

Variables

USEFUL

RECOGNITION

INVOLVEMENT

$\begin{array}{lllllll} & \text { Estimate } & \begin{array}{l}\text { Marginal } \\ \text { effects }\end{array} & \text { Estimate } & \begin{array}{l}\text { Marginal } \\ \text { Effects }\end{array} & \text { Estimate } & \begin{array}{l}\text { Marginal } \\ \text { Effects }\end{array} \\ \text { STANDARD } & 0.87 * * * & 0.09 * * * & - & - & - & - \\ & (0.26) & (0.03) & & & & 0.87 * * * \\ \text { USEFUL } & - & - & - & - & 0.24 * * * \\ & & & & & (0.23) & (0.06)\end{array}$

LR test of joint nullity of correlation coefficients: $\operatorname{chi} 2(3)=13.54 * * *$

$\begin{array}{lllllll}\text { STANDARD } & - & - & 0.38^{* * *} & 0.03 * * * & - & - \\ \text { RECOGNITION } & - & - & (0.12) & (0.01) & & \\ & & & - & - & 0.67 * * * & 0.09 * * * \\ & & & & (0.25) & (0.03)\end{array}$

LR test of joint nullity of correlation coefficients: $\operatorname{chi} 2(3)=6.91 *$

$(*),(* *),(* * *)$ indicate parameter significance at the 10,5 and 1 percent levels, respectively. The obtained results are based on 500 random draws for the multivariate probit model. The marginal effects are computed for the average employee of the population. Standard Errors in parentheses. 
Appendix 1: Pearson correlation coefficients

\begin{tabular}{|l|l|}
\hline & EXPORT \\
\hline EXPORT & 1.00 \\
\hline USEFUL & $-0.019(0.26)$ \\
\hline RECOGNITION & $0.012(0.87)$ \\
\hline INVOLVEMENT & $0.021(0.172)$ \\
\hline $\begin{array}{l}\text { NON COMPENSATED } \\
\text { OVERTIMES }\end{array}$ & $0.011(0.90)$ \\
\hline
\end{tabular}

$* \mathrm{p}<0.01 ;$ significance level in parenthesis.

Appendix 2. Bivariate probit estimates of the effect of environmental standards on employee's attitudes, job involvement and effort (without temporary contracts workers)

USEFUL RECOGNITION INVOLVEMENT NON COMPENSATED OVERTIMES

\begin{tabular}{|c|c|c|c|c|}
\hline $\begin{array}{l}\text { Impact of STANDARD on the } \\
\text { average employee in the } \\
\text { population }\end{array}$ & $\begin{array}{l}0.071 * * \\
(0.036)\end{array}$ & $\begin{array}{c}0.032 * * * \\
(0.011)\end{array}$ & $\begin{array}{l}0.026 \\
(0.017)\end{array}$ & $\begin{array}{l}0.040 * * \\
(0.015)\end{array}$ \\
\hline $\begin{array}{l}\text { Average Treatment Effects of } \\
\text { STANDARD }\end{array}$ & $\begin{array}{c}0.11 * * * \\
(0.046)\end{array}$ & $\begin{array}{c}0.13 * * * \\
(0.045)\end{array}$ & $\begin{array}{c}0.08 \\
(0.050)\end{array}$ & $\begin{array}{c}0.15 * * * \\
(0.056)\end{array}$ \\
\hline $\begin{array}{l}\text { Impact of STANDARD on the } \\
\text { average employee in the } \\
\text { population (long term } \\
\text { contracts only) }\end{array}$ & $\begin{array}{r}0.078^{* *} \\
(0.039)\end{array}$ & $\begin{array}{c}0.033 * * * \\
(0.012)\end{array}$ & $\begin{array}{l}0.025 \\
(0.017)\end{array}$ & $\begin{array}{c}0.040 * * * \\
(0.016)\end{array}$ \\
\hline $\begin{array}{l}\text { Average Treatment Effects of } \\
\text { STANDARD (long term } \\
\text { contracts only) }\end{array}$ & $\begin{array}{l}0.11 * * * \\
(0.046)\end{array}$ & $\begin{array}{l}0.14 * * * \\
(0.051)\end{array}$ & $\begin{array}{c}0.07 \\
(0.049)\end{array}$ & $\begin{array}{l}0.14 * * * \\
(0.057)\end{array}$ \\
\hline
\end{tabular}

$(*),(* *),(* * *)$ indicate parameter significance at the 10,5 and 1 percent levels, respectively. Standard Errors in parentheses. 
Appendix 3a. Multivariate probit estimates of the relationship between environmental standards, employee's attitudes toward job and employee's job involvement (instrumental variable: INTERRUPT)

Variables

USEFUL

RECOGNITION

INVOLVEMENT

$\begin{array}{lllllll} & \text { Estimate } & \begin{array}{l}\text { Marginal } \\ \text { effects }\end{array} & \text { Estimate } & \begin{array}{l}\text { Marginal } \\ \text { Effects }\end{array} & \text { Estimate } & \begin{array}{l}\text { Marginal } \\ \text { Effects }\end{array} \\ \text { STANDARD } & 0.84^{* * *} & 0.08^{* * *} & - & - & - & - \\ & (0.26) & (0.03) & & & & \\ \text { USEFUL } & - & - & - & - & 0.79 * * * & 0.22 * * * \\ & & & & & (0.24) & (0.06)\end{array}$

LR test of joint nullity of correlation coefficients: $\operatorname{chi} 2(3)=12.26^{* * *}$

$\begin{array}{lllllll}\text { STANDARD } & - & - & 0.39 * * * & 0.03 * * * & - & - \\ \text { RECOGNITION } & - & - & (0.12) & (0.01) & & \\ & & & & - & 0.55^{*} & 0.07 * * \\ & & & & (0.28) & (0.03)\end{array}$

LR test of joint nullity of correlation coefficients: $\operatorname{chi} 2(3)=6.07$

$(*),(* *),(* * *)$ indicate parameter significance at the 10,5 and 1 percent levels, respectively. The obtained results are based on 500 random draws for the multivariate probit model. The marginal effects are computed for the average employee of the population. Standard Errors in parentheses.

Appendix 3b. Multivariate probit estimates of the relationship between environmental standards, employee's attitudes toward job and employee's job involvement (instrumental variable: EVALUATION)

Variables

USEFUL

RECOGNITION

INVOLVEMENT

$\begin{array}{ll}\text { Estimate } & \begin{array}{l}\text { Marginal } \\ \text { effects }\end{array} \\ 0.83^{* * *} & 0.08^{* * *} \\ (0.24) & (0.03)\end{array}$

Estimate Marginal

Estimate

Marginal

Effects

Effects

STANDARD

$$
\text { (0.24) }
$$

$-$

$$
-
$$

USEFUL

(20)

$-$
- $\quad 0.96 * * * \quad 0.26 * * *$
$(0.20) \quad(0.06)$

LR test of joint nullity of correlation coefficients: $\operatorname{chi} 2(3)=15.28 * * *$

$\begin{array}{lllllll}\text { STANDARD } & - & - & 0.35^{* * *} & 0.03 * * * & - & - \\ \text { RECOGNITION } & - & - & (0.11) & (0.01) & & \\ & & & - & - & 1.22^{* * *} & 0.14 * * * \\ & & & & (0.13) & (0.03)\end{array}$

LR test of joint nullity of correlation coefficients: $\operatorname{chi} 2(3)=21.68^{* * *}$

$\left(^{*}\right),(* *),(* * *)$ indicate parameter significance at the 10,5 and 1 percent levels, respectively. The obtained results are based on 500 random draws for the multivariate probit model. The marginal effects are computed for the average employee of the population. Standard Errors in parentheses. 